\title{
PLANNING OF LECTURER QUALITY DEVELOPMENT OF STATE ISLAMIC HIGHER EDUCATION IN ACEH
}

\author{
Husaini \& Jumat Barus \\ Institut Agama Islam Negeri Lhokseumawe \\ Jl. Medan-Banda Aceh Km. 275 No. 1, Lhokseumawe, Aceh \\ e-mail: husaini@iainlhokseumawe.ac.id,jumatbarus@iainlhokseumawe.ac.id
}

\begin{abstract}
This research was conducted to examine and explain how the planning of lecturer quality development was carried out by the State Islamic Colleges in Aceh. This study used qualitative design with three State Islamic Colleges in Aceh as the objects and locations. The data was obtained through interview and documentation techniques from related officials of the colleges concerned. The results showed that the planning of lecturer quality development of the universities had been set in their strategic plan with three focuses, they are plans to turn lecturers into experts in their fields; plans to develop lecturer expertise; and plans to increase research and community service. The institutions generally have the same commitment to make various good and sufficient plans for the development of the lecturer quality both in terms of capacity and professionalism, however there are two important aspects that determine policy makers in determining their plans.
\end{abstract}

Abstrak: Penelitian ini dilakukan untuk mengkaji dan menjelaskan bagaimana perencanaan pengembangan kualitas dosen yang dilakukan oleh Perguruan Tinggi Keagamaan Islam Negeri di Aceh. Penelitian ini menggunakan desain kualitatif dengan tiga Perguruan Tinggi Keagamaan Islam Negeri di Aceh sebagai objek dan lokasi. Data diperoleh melalui teknik wawancara dan dokumentasi dari pejabat perguruan tinggi terkait. Hasil penelitian menunjukkan bahwa perencanaan pengembangan kualitas dosen telah diatur dalam dokumen rencana strategis dengan tiga fokus, yaitu rencana menjadikan dosen ahli di bidangnya; rencana pengembangan keahlian dosen; dan rencana peningkatan penelitian dan pengabdian masyarakat. Ketiga institusi yang dikaji secara umum memiliki komitmen yang sama untuk membuat berbagai perencanaan yang baik dan memadai untuk pengembangan kualitas dosen baik dari sisi kapasitas maupun profesionalisme, namun terdapat dua aspek penting yang memengaruhi pengambil kebijakan dalam menentukan perencanaannya.

Keywords: Islamic higher education, Aceh, lecturer, competence, quality, planning 
Husaini \& Jumat Barus: Planning of Lecturer Quality Development

\section{Introduction}

Education is a very important need in human life, so that the progress of a nation depends very much on the implementation of the education in that country. One of the most important elements in improving education is qualified lecturers. This had been explained by several previous researchers, such as Ramdhan and Siregar who stated that one way to build universities in this globalization era is by improving the quality and welfare of lecturers. ${ }^{1}$ Razak et al. who found that lecturer performance has a positive and significant contribution and influence on the quality of education, thus the performance of lecturers contributes to improving the quality of higher education. ${ }^{2}$ Muhtifah et al. who obtained that improving the quality of the institution is an integral part with all elements existed. ${ }^{3}$ Kusnan found out the implementation of the duties and responsibilities of the lecturer always need to be controlled and developed in such a way so that it is more optimal and relevant to existing needs. ${ }^{4}$ Kemal et al. who stated that to develop lecturer resources, the campus provides incentives for lecturers who have successfully published research articles and devoted to high-reputed international journals. ${ }^{5}$

The problem of the inequality between the qualities of education, namely the discrepancy of university graduates with the qualifications required by the business is a reflection of a fundamental weakness in education system. Related to this, Lisnasari found that university quality management including lecturers have relationship with job satisfaction of human resources. ${ }^{6}$ These problems cannot be separated from the quality of educators or lecturers in a university, and the quality of the lecturers also depends very much on the strategy or activity done by a university and how the university develops the lecturers' quality and professionalism so that it can produce qualified output (graduates). In general, it is known that the profession of lecturer is as an "educator", and this is ruled in the constitution of Republic of Indonesia Number 20/2003 concerning the National Education System. ${ }^{7}$ In

${ }^{1}$ Dadan F. Ramdhan and Hariman Surya Siregar, "Manajemen Mutu Perguruan Tinggi Keagamaan Islam Swasta (PTKIS)," in Jurnal Perspektif, Vol. 3, No. 1, Mei 2019, pp. 75-109.

${ }^{2}$ Yusran Razak, et al., "Kepemimpinan, Kinerja Dosen dalam Peningkatan Mutu Pendidikan Perguruan Tinggi," in TANZIM Jurnal Penelitian Manajemen Pendidikan, Vol. 1, No. 2, 2016, pp. 30-44.

${ }^{3}$ Lailial Muhtifah, et al., "Jaminan dan Peningkatan Kualitas Dosen melalui Program Doktor pada PTKIN di Indonesia," in ALFIKR: Jurnal Pendidikan Islam, Vol. 4, No. 2, Desember 2018, pp. 27-33.

${ }^{4}$ Kusnan, "Kebijakan Peningkatan Mutu Dosen," in Jurnal Pendidikan Islam Iqra', Vol. 11, No. 2, 2017.

${ }^{5}$ Isthifa Kemal, et al., "Management of Lecturers Resource Development at Higher Education," in International Journal of Higher Education, Vol. 8, No. 5, 2019, pp. 246-256.

${ }^{6}$ Srie Faizah Lisnasari, "The Quality Management of Higher Education on the Job Performance of Lecturers Basis," in Advances in Social Sciencies Research Journal, Vol. 5, No. 11, 2018, pp. 158-177.

${ }^{7}$ Undang-Undang Republik Indonesia Nomor: 20 tahun 2003 tentang Sistem Pendidikan Nasional, in section 39 (2): educators are professionals who are tasked with planning and 
addition, the constitution of the Republic of Indonesia Number 14/2005 concerning Teachers and Lecturers also specifically regulates lecturers, lecturers' guidance and development, as well as policies for its development and guidance. ${ }^{8}$

Based on the provisions that have been regulated in several regulations above, it is understood that universities are obliged to improve the lecturers' quality. Universities are also obliged to set criteria for lecturers and lecturer quality management in order to achieve the goals of lecturer professionalism. The lecturer quality management is aimed at empowering the lecturers so that they can perform as good as possible in shaping and producing high quality students as alumni. In order to make lecturers carry out their duties and functions satisfactorily, so it is needed conditions that provide opportunities and encourage lecturers to develop their expertise or professionalism in order to do their job better and satisfactorily. In addition, institution is obliged to create good system as a systematic effort to develop lecturers' professional skills. In addition, the institution must also determine the criteria for lecturers and lecturer quality management to realize lecturers with high professionalism, with criteria; (a) Expertise, (b) Development of expertise, (c) Applying instructional technology, and (d) Applying ethics in teaching, researching, and professional activities. ${ }^{9}$ Lecturers' development has become a real need for efforts to the improvement the quality of human resources for higher education through systematic, coherent, measurable and organized processes. This is in line with Castetter's opinion, that the development should be considered as an activity to increase the professionalism or ability of individuals or groups so that they become more responsible in running the system that has been formalized. ${ }^{10}$

implementing the learning process, assessing learning outcomes, conducting mentoring and training, as well as conducting research and community service, especially for educators at universities; section 40 (2.a) Generating educational atmosphere that is meaningful, fun, creative, dynamic and dialogical; (2.b) Educators have a professional commitment to improve the education quality; (2.c) To exemplify and maintain the prestige of the institution, profession and position in accordance with the trust given. Section 42 (1) Educators must have minimum qualifications and certification in accordance with the level of teaching authority, physically and mentally healthy and have the ability to realize the goals of national education.

${ }^{8}$ Undang-Undang Republik Indonesia Nomor: 14/2005 tentang Guru dan Dosen, in section 1 (2): Lecturers are professional educators and scientists with the main task of transforming, developing, and disseminating science, technology and art through education, research, and community service; Section 69 (1) Fostering and developing lecturers include guidance and development of career and profession; (2) Fostering and development of lecturers profession referred to subsection (1) includes pedagogical competence, personality competence, social competence, and professional competence; (3) Fostering and developing lecturers' career is carried out through functional positions as referred to subsection (1); and (4) The fostering and development of lecturers career as referred to subsection (1) includes assignments, promotions; Section 70: Strategic policies for the guidance and development of lecturers' professions and careers in higher education units organized by the Government or community are decided by a Ministerial Regulation.

${ }^{9}$ Masluyah Suib, "Kebijakan dan Pengembangan Mutu Dosen," in Cakrawala Kependidikan, Vol. 9, No. 2, September 2011.

${ }^{10}$ William B. Castetter, The Personnel Function in Educational Administration (3rd Edition) (London: Collier Macmillan Publishers, 1981), p. 51. 
Currently, Aceh Province has five State Islamic Religious Colleges with more or less 2,308 lecturers with Masters and Doctoral degrees. ${ }^{11}$ Those of lecturers are spread across the five institutions. The development of lecturer quality in these institutions is generally carried out by considering various important things that have been described above, however the focus, management, and internal conditions have important role and greatly affect the implementation of all the quality development activities concerned. In several ways, it is known that the university which has better facilities, infrastructure, and human resources can certainly carry out more activities to develop their lecturers' quality than that of institutes and colleges. Therefore, this research aims to examine and explain the planning carried out by those colleges in Aceh in developing the quality of their lecturers.

\section{Methodology}

This study applied descriptive analytic research method by using qualitative approach. This approach has characteristics, namely: data were taken from direct sources in a reasonable situation, descriptive in nature, prioritizing process over results, descriptive data analysis, and describing the symptoms appeared in the field whose content and meaning can be interpreted. ${ }^{12}$ This research was conducted at three State Islamic Religious Colleges in Aceh province, namely: State Islamic University of Ar Raniry Banda Aceh, State Islamic Institute of Langsa, and State Islamic College of Gajah Putih, Takengon. These three Islamic colleges were selected taking into account the need to obtain accurate data and were considered to be representative of the five colleges in Aceh. The data of the research are information about planning of lecturer quality development contained in those colleges' Strategic Plan document and the information obtained from policy makers and officials who are directly involved in the quality development management activities of lecturers. Data were collected by using field and library methods with interview and documentation techniques. The data collected were analyzed in three stages, namely unitization, categorization, and interpretation.

\section{Results and Discussion}

\section{Planning of Lecturer Quality Development of State Islamic University}

Planning of lecturer quality development of State Islamic University (UIN) in Aceh is part of the management process flow that carry out by the university in determining its development from its current position to the target position in the future. Therefore,

${ }^{11}$ Data EMIS PTKI - Dashboard Monitoring, accessed from http://emisdep.kemenag.go.id/ ptkidashboard/ on 23 September 2020.

${ }^{12}$ Robert C. Bogdan and Kopp Sari Biklen, Qualitative Research for Education: An Introduction to Theory and Methods (Boston London: Allyn and Bacon Inc, 1982). 
the quality parameters are lecturers' competence and professionalism in academic teaching, research, and community service. Besides that, the lecturers' quality is also shown by positive changes in the three aspects of their student potential, included cognitive, affective and psychomotor aspects as the impact of the learning process. At the final stage, the quality can be seen from the condition of its graduate's quality as a product of the learning process that lasts for several periods.

Planning is the first step in defining and discussing measurable roles, responsibilities and expectations in order to achieve institutional goals. The urgency of quality development planning for lecturers in Aceh is as guidelines for policy makers in taking concrete steps to make improvements, fostering, and developing the quality of human resources, especially lecturers, so that it has a positive impact on the output, qualified graduates. Creativity is needed to survive and not be vulnerable to various difficulties, so that the institution keeps on competing with others at the national and international levels. Thus, one of the objectives of the formulation of the lecturer quality development plan is to become guidelines for the implementation of the quality development of lecturers at State Islamic University in Aceh. Through the formulation of the lecturer quality development plan, the policy maker can more easily lead, direct, and foster the lecturers towards the expected goals.

The existence of planning that is carried out and outlined in the strategic plan document, shows that long time before, the university had planned to improve not only the quality of its lecturers but also the fulfillment of the ratio between lecturers and students. This is mentioned in its strategic plan, as follows:

In the last two years of the first phase of the Strategic Plan, the university has included several management issues such as the succession of leadership in 2018, fulfillment of lecturer ratios, and re-accreditation of institutions. (particularly, strengthening literacy capacity of educators and officials (especially improving the quality of research and structuring study programs as well as academic administration). ${ }^{13}$

Quality development is indicated by a phrase "strengthening literacy capacity of educators, especially improving the quality of research and structuring study programs and academic administration". The university has a high commitment to improve the quality and quantity of its human resources, especially lecturers. The plan to develop the quality of lecturers in this section focuses on the quality of research and the arrangement of study programs and academic administration. The structuring of the study program in this case involves many things one of which is the quality of lecturers. It is understood that the intended structuring of lecturers is related to the suitability of a balanced lecturer's scientific field in accordance with the needs of the field of study program at the university.

In its strategic plan, the State Islamic University states that there are eleven strategic

${ }^{13}$ Rencana Strategis (Renstra) Universitas Islam Negeri Ar Raniry Banda Aceh Tahun 20152019, p. 136. 
targets which will be their main focus. Of the eleven strategic targets, three of them are in the lecturer sector, specifically at points 6, 7, and 8, as follows:

6. Improvement of the professionalism of teaching staff and educational staff. The university needs to develop the professionalism of teaching staff and education staff.... the number of teaching staff who are in accordance with the field of study continues to be strived to achieve the ideal ratio in addition to the number of teaching staff in accordance with the appropriate field is increasingly rationalized. The next effort is to increase the percentage of lecturers with Doctoral qualifications and the addition of new professors.

7. The improvement of the quality and qualifications of lecturers.

The quality of higher education is largely measured by the quality and qualifications of teaching staff and education personnel. Therefore the university continues to strive to improve the quality and qualifications of teaching staff and educational staff. In 2019 it is targeted that there will be 20 professors at the university. In addition, the number of teaching staff in accordance with the field is getting closer to the ideal ratio, which is 1:20 in 2019.

8. Development of the research ability for lecturers and students.

The development of research abilities for lecturers and students is caused by the increasing number of trainings exercised to lecturers and students.... ${ }^{14}$

The three points that become the strategic targets of the university show a high commitment in terms of lecturer quality development. The university plans to improve the quality of its lecturers by increasing the educational capacity of its lecturers by the improvement of the lecturers' qualifications with Doctoral degree and accelerating professorships. Through this strategic goal, the university has a high commitment to make better improvements to the quality of the lecturers. Increasing lecturers with Doctoral degrees will of course send lecturers to take part in further studies of S3. By following these further studies, the quality and scientific capacity of the lecturers will automatically be increased.

Likewise with plans to increase the number of professors, the plan shows the institution's efforts to improve the quality of lecturers. It is in accordance with the Indonesian Constitution Number 14/2005 concerning Teachers and Lecturers, that Professor is the highest functional position for lecturers who are still in teaching at a higher education unit. If previously lecturers with Master degrees (S2), even undergraduate (S1) could become professors, since 2007 those who have doctoral degrees only can become professors. Thus, the university has made good plans in developing the quality of its lecturers. In point 8 of its strategic goal, it states that the university will increase the capacity of lecturers in researching. Researching is one part of the three responsibility of higher education, and it is a must for lecturers to be able to research well. Therefore, the institution will perform various research trainings for lecturers, so that the lecturers will be skillful in conducting various researches.

${ }^{14}$ Ibid., pp. 140-141. 
In the Strategic Plan, in some points (e, g, h, and o) in Strategic Work Program section in strengthening the academic, educational and teaching fields, it is stated as follows:

e) Improving quality.... and requiring lecturer evaluation by students at the end of each semester.

g) Facilitating lecturers to improve their academic qualifications through studies in postgraduate programs in accordance with their S2 study program (continuing studies to linear S3 programs), short courses, training, presenting of research results at conferences and other academic events.

h) Encouraging lecturers, administration staff and technical staff... to use ICT optimally and responsibly.

o) Recruiting lecturers in need and reliable administrative staff refers to the available formations and the needs of each study program and student service unit through strict selection regarding academic qualifications and professional abilities as lecturers and staff. Restrictions on the transfer of administrative personnel to become lecturers need to be maintained and the recruitment of collusive lecturers and staff should be stopped..$^{15}$

The strategic program contained in point e) shows an effort to develop the quality of lecturers through a policy that requires students to evaluate the lecturers at the end of each semester. Through such a program, the institution believes that the lecturers will automatically try to always update and upgrade their abilities with the up to date sciences related to their knowledge. In addition, at point $g$ ) the university clearly states to facilitate lecturers in Master degrees to increase their academic qualifications at the Doctoral level in accordance with the knowledge needed in their postgraduate program. This makes the lecturers very easy to be able to gain knowledge at the doctoral level without having to leave the campus which requires a large budget. The program, which is used as a strategic target, is a good initial commitment to quality development, especially for lecturers.

The university's plan to develop the quality of its lecturers is also seen in the Strategic Work Program (point $b$ and $f$ ) in strengthening the lecturers on the field of research and scientific publications.

b) facilitating lecturers and students in conducting research and community service, including collaborative research for lecturers and students through the easiness of proposal preparation, access to activity targets and sources of funding, writing reports, and utilization of the results of further activities, up to obtaining intellectual property rights.

f) Facilitating the lecturers becomes visiting professor at universities which have been collaborated with to broaden their scientific insights and academic experiences. ${ }^{16}$

In this case, lecturers are planned to be given various facilities in carrying out

${ }^{15}$ Ibid., pp. 155-156.

${ }^{16}$ Ibid., pp. 157-158. 
research and community service. This is very helpful for lecturers, because the institution always supports everything needed by the lecturers in implementing the responsibility of higher education. This can also be seen in the Strategic Work Program in reinforcement the field of community service and cooperation, that the institution plays an active role in providing media for its lecturers to improve their knowledge and academic experience. They will be more easily to make collaborations research with other lecturers from various universities within the country and universities abroad.

Apart from being set in their strategic plan, the plan for developing the quality of lecturers at the university was also discussed in several meetings, especially at the end of the semester and the end of the year. Actually the meeting was not specifically held to discuss the planning for development of the lecturers' quality, but became an integrated agenda in the end of semester and year routine meetings. The meeting involved all elements of the functionary of the institution, faculty, unit, and lecturers. Planning for the quality development program at the university is carried out openly at general meetings at the end of each year or welcoming the next academic year. This means that the formulation of the program plan for quality development is carried out openly by absorbing inputs from various parties involved in the meetings. ${ }^{17}$ This is intended to ask for and receive complete input on matters that are needed by lecturers, become a strategic program for the institution, as well as an opportunity for the management to disseminate obligation matters for lecturers based on government standards.

Furthermore, the planning of the lecturer quality development program at the university is basically discussed in a work meeting at the beginning of the year which involves all university functionary and lecturers. Likewise, when it is viewed from the material of the meeting, it discusses lecturer performance standards and assessment indicators, strategic programs to improve lecturer competence and professionalism, and so on. ${ }^{18}$ Planning that has been determined in the strategic plan, is followed up with discussions at the leadership and lecturer meeting. The meeting resulted in several recommendations, including providing the widest possible opportunity for lecturers to continue their studies by trying to acquire scholarships from government and private scholarship providers, and supporting the ability of lecturers to write scientific papers to be published in reputable national and international journals.

The development of lecturer quality at this university is not only in their academic capacity but also has carried out the planning of quality development in the field of research and community service. Those lecturers who successfully publish their scientific papers in accredited national journals or in reputable international journals will be rewarded.

\footnotetext{
${ }^{17}$ Mizaj, Quality Assurance of State Islamic University of Ar Raniry, interview in Banda Aceh, August 2, 2019.

${ }^{18}$ Bukhori Muslim, Quality Assurance of State Islamic University of Ar Raniry, interview in Banda Aceh, August 2, 2019.
} 
Indeed, this planning his will trigger an increase in the lecturers' interest to improve their abilities in researching, writing and finding ways to be able to publish their work as soon as possible. This of course occurs due to the policies of the policy makers who focus on developing the quality of the teaching staff.

In the formulation of the Lecturer performance supervision program and the development of Lecturer competence as part of the planning for developing the quality of lecturers, the high officials have a decisive role. This happens because of several things, namely: first, hierarchically, the leadership of higher education is the high officials in the organizational structure, where the lecturers are responsible to them; second, the high officials have the authority and interest in higher education quality assurance so that they must be involved from the beginning in the formulation of the programs concerned; and, third, the high officials need to know more about the substance of the programs concerned, in order to consider the financial capacity aspect of the implementation of these programs. On the other hand, the process of formulating a lecturer quality development program in the planning stage is pursued through the improvement and refinement of a number of components ranging from formulation, concepts and main responsibility of lecturers, methods and techniques for monitoring lecturer performance, strategies for improving Lecturer performance and developing lecturer competence, selection pattern of lecturer recruitment, lecturer career guidance and development, as well as the provision of awards and allowances for educators and education personnel who have a high quality work.

From the analysis above, it can be understood that the university has good goals and plans in developing the quality of their lecturers. The university has various plans in it, in terms of increasing academic qualifications and increasing the literacy capacity of lecturers. In the planning, the university will recruit prospective lecturers who have the best abilities and qualifications. That will be the basic capital for the university in the side of human resources, so that they can be easier to provide support to develop the lecturers' competence and professionalism into higher quality lecturers. The university has a program to strengthen the literacy of lecturers, namely in terms of programs to improve the quality of research results and community service. Of course, this will also have an impact on increasing the lecturers' ability to publish their scientific works in some reputable international journals. This effort is not only limited to training implementation, but also the university is giving award to those lecturers who have successfully published their research in accredited national journals and reputable international journals. This strategy will certainly attract the lecturers' interest to seriously do their best so that the results of their research can be published in the best rated journals. In addition, lecturers are also given freedom to disseminate their knowledge by being guest lecturers at various institutions, both inside and outside Aceh. Various programs have been stated in the strategic plan; this has met the criteria of lecturers expected by the law, namely in terms of expertise, teaching, research, professionalism. The institution has high self-confidence and courage to create various programs in the 
development of the lecturers' quality, because as a university, this institution has sufficient human resources, sufficient financial resources, and various facilities to support the implementation of these programs.

\section{Planning of Lecturer Quality Development of State Islamic Institute}

Planning for developing the quality of lecturers at the State Islamic Institute (IAIN) in Aceh has also been accommodated in the Strategic Plan of the institute. In the 20152019, IAIN Langsa its Strategic Plan at point 4.1 regarding institutional capacity, there are 4 main strategies that are planned to be developed and achieved gradually, one of which is about increasing the capacity of human resources, as follows:

...Includes all activities and programs aimed at empowering the human resources of IAIN Langsa which consists of educators and education staff in the fields of pedagogic, professional, service and research competences as well as Muslim and social personality qualifications. Through this agenda, it is hoped that IAIN Langsa can increase stakeholders' satisfaction in the quality of education and teaching along with the increasing quality and quantity of teaching and education personnel. ${ }^{19}$

In the above quotation it is implicitly stated that the development of the quality of lecturers is an important thing to do, so it is stated that all activities and programs are aimed at empowering human resources, and it is clearly known that the human resources referred to in particular are lecturers, because they are related to the field pedagogical competence, professional, and competence in the field of research. It can also be understood that lecturers are the main target in this regard, because the human resources that are directly related to the development of the quality of education and teaching are none other than lecturers. Thus, IAIN Langsa concluded that it has a good plan in developing the quality of its lecturers, both through increasing scientific capacity and academic level.

The explanation above is in line with the information on IAIN Langsa's plan in developing the quality of lecturers, which was obtained in the interview at the campus:

Planning for the development of the quality of lecturers in Aceh is based on the consideration that the development of the quality of lecturers can be seen through the quality of their graduates, and good graduates will not be achieved without preparing qualified and professional teaching staff. Since the beginning, even from the process of recruitment of the lecturers, the program has been prepared. In addition, we have also prepared several other lecturer performance improvement programs, such as the work meeting program at the beginning of the year, and the lecturer performance evaluation program at the meeting at the end of each semester. Meanwhile, regarding the Lecturer competency development program, that is the lecturer training program for career development.

${ }^{19}$ Rencana Strategis (Renstra) Institut Agama Islam Negeri Langsa Tahun 2015-2019, p. 20. 
Through these prepared programs, it is hoped that the quality of the resources will be increased in the future. ${ }^{20}$

The planning of lecturer quality development that is carried out by IAIN Langsa is focused on two main programs, namely the lecturer performance monitoring program and the lecturer competence and professionalism enhancement program. The lecturer performance monitoring program is carried out through work meetings at the beginning of the year and lecturer workload, evidence of lecturers' visit and attendance in the class, and performance evaluation each year

The plan of quality development is also carried out in the plan of increasing the lecturers' academic capacity through further studies in S3 program. In this case, the leaderships do not limit it, and planning to provide widest possible opportunity for lecturers of Magister degree to carry out further studies with the funding offered by several scholarship providers. In addition, this institution will provide reasonable rewards for lecturers who write in national and international journals.

We support and motivate lecturers to immediately follow further studies, and previously tried to get scholarships from existing scholarship providers and the private sector who have a good commitment in this regard. In addition, we have also planned to provide amount pf money as rewards, for those who are able to publish their scientific papers in accredited national journals, as well as reputable international journals. Besides that, we also have an acceleration program for professors in the year of $2021 .^{21}$

Things explained above is also strengthened by the results of other result of interviews, which state that:

One of the discussions at the early year meeting was related to quality development efforts and lecturer evaluation. Among them were discussed about the presence of lecturers. As a complement to these programs, the intitutes leaders have also made several policies to improve the competence of lecturers, such as conducting training and providing opportunities for lecturers to participate in various academic and training activities, seminars and writing international journals as well as opportunities to carry out further studies at universities both within country and overseas. ${ }^{22}$

These policies are discussed at lecturer meetings to gather information and at the institute leaders level meetings to be discussed in more detail. This institution has a lecturer quality development program in the field of research and community service, and will reward lecturers who are able to publish their scientific works in accredited national journals and reputable international journals. In addition, currently IAIN Langsa has a 9, 2019.

${ }^{20}$ Yusaini, Quality Assurance, State Islamic Institute Langsa, interview in Langsa, Agustus

${ }^{21} \mathrm{Ibid}$.

${ }^{22}$ Ibid. 
professor acceleration program for several lecturers who have certain conditions, and in this case they are determined to have Professors in 2021.

From the analysis above, it is concluded that this institution also plans to develop the quality of lecturers that are not inferior to several programs conducted by higher education at the university level. In order to meet the need for high-quality lecturers, the institution does so from the implementation of recruitment to providing opportunities for lecturers to take part in further studies, training, seminars, and even professor acceleration. In this case, the institution has various plans in developing the quality of lecturers, which includes two important things, namely: competency development and lecturer professional development. Plans or programs to improve lecturer competence are carried out by encouraging and providing moral assistance for lecturers with Masters degree to undertake further Doctoral studies at various leading universities, both within country and abroad by using various scholarship financial facilities from both the government and private sector scholarship providers. In addition, the institution carries out various trainings to improve the academic abilities of lecturers. Plans to develop quality in the professional field of lecturers, this institution plans to carry out various training activities, seminars, and assistance in improving lecturer functionalities, especially in terms of accelerating professorships. Lecturers are also given various support facilities in participating in research activities and community service, and provide opportunities to carry out various collaborative researches with lecturers from other universities.

Compared with the State Islamic University, surely this State Islamic Institute has several shortcomings or weaknesses caused by several conditions. The shortage is caused by the availability of human resources and lack of funds and source of funding. The condition causes the policy makers planned only programs that are considered very important and urgent not only in lecturer' divisions but also the other divisions based on the availability of funds and the sources of funds they have. This is considered not a wrong thing, because indeed the development of the quality of lecturers is not the only important thing that must be funded. Apart from the lecturer quality development program, development in other sections in the institute is also important for the running of a college.

\section{Planning of Lecturer Quality Development of State Islamic College}

As it is stated in State Islamic University and State Islamic Institute above, the development of the quality of lecturers at the State Islamic College (STAIN) of Gajah Putih, Takengon also begins with a planning stage as outlined in the institution's strategic plan. In the strategic plan, it is stated that in the short-term program (1-2 years) on points $\mathrm{e}, \mathrm{f}$, and $\mathrm{h}$ are stated as follows:

e. The improvement of human resources, infrastructure, and academic services

1) Continuing studies for lecturers, participating in academic activities, and increasing educational support facilities 
2) Expanding information services through faster internet access.

f. Increasing lecturer research through (1) basic and advanced research training, (2) the involvement of lecturers in competitive research and competitive grants in national level, (3) increasing the number of lecturers participating in research network seminars.

h. Strive to improve lecturers' English and Arabic skills. ${ }^{23}$

From the strategic plan quoted above, it can be seen that the development of the quality of lecturers at this institution is divided into short-term, medium-term and longterm programs. In this section, it is stated that in the short term (1-2 years) there is a good plan regarding the development of the quality of lecturers, both in academic capacity and in developments concerning the professionalism of lecturers. The quality development program in terms of academic capacity, the STAIN has planned to improve the lecturer education level by granting of permits and facilities for lecturers to continue further studies for lecturers who still in Masters degree to S3 (Doctoral) program, since there are some lecturers, especially new lecturers who do not have a Doctorate degree. Meanwhile, with regard to support for the lecturer professionalism, this institution will send the lecturers to join in various academic activities, not only in teaching but various academic matters such as trainings, seminars, and others. Related to this, it is clearly written that lecturers will be given reinforcement in Arabic and English skills. This is absolutely needed in facing competition in the globalization era, so that lecturers can compete with those lecturers from leading universities both within country and abroad.

In addition, this College also has a good plan in terms of developing the quality of lecturers in the research field. This institution is serious about providing various trainings to conduct research and will involve them in various competitive research and competitive grants both domestic and abroad. That program is very useful for lecturers to improve their ability to conduct research and get better results, so that they can published the research result in various reputable national and international journals. It is very beneficial, in addition to developing the professionalism of the lecturers, and it will also accelerate the functional improvement of the lecturers.

In addition to development planning in the short-term program, in another section, the development of the quality of lecturers is also stated that:

To accelerate the academic management programs above, activities are designed, including:

a. Preparing qualified, professional, and competent structural and functional academic staff.

${ }^{23}$ Rencana Strategis (Renstra) Sekolah Tinggi Agama Islam Negeri Gajah Putih, Takengon Tahun 2013-2029, p. 20. 
b. Cultivating a pleasant lecture service (learning partners relationship between lecturers and students).

c. Developing curriculum..... ${ }^{24}$

The short excerpt in this section shows that the College its seriousness to develop the lecturers' quality. They have an extraordinary initial commitment to the development concerned, they target up to qualified, professional, and competent lecturers. This goal is truly a product of high self-confidence. Even though the institution is still at the college level, the policy makers are sure and confidence that they will do their best to achieve a qualified, professional, and competent qualification. To reach the goal of making lecturers at the level as mentioned, of course, it will require some important aspects that must be fulfilled, especially the readiness of the lecturers' resources themselves, and also the most important thing is the availability of funds that are very much needed in all the programs to be implemented. But, there is a word that keeps them from being in such a difficult condition, which is the word "preparing". This word is important, that they have not set the target for qualified, professional, and competent lecturers, but are still at the level of trying to do or do various things to prepare the lecturers to reach that level. It becomes natural and very possible.

Moreover, the development of lecturer quality is also mentioned in the long-term program, that the lecturers of the State Islamic College are planned to be professional and reliable in their respective expertise, and the institution has target to have two Professors during the ten years. This plan is considered rational because in the strategic plan, it is also explained the way how to achieve the strategic achievements per year, namely: that to achieve good academic capacity of lecturers, lecturers are sent continue their studies at Doctor degree, and increase the participation of lecturers in various academic activities, such as training, seminars, and short courses. Furthermore, in increasing quality in the lecturers' research, STAIN conducts various basic and advanced research trainings, involves lecturers in competitive research and national level competitive grants. Related to the improvement of lecturers' English and Arabic skills in the lecture process, STAIN plans to achieve this by providing regular English language training and article writing training in English and Arabic. STAIN has also planned coaching and development of lecturer quality which is focused on improving the quality of lecturers to be able to teach according to their fields of expertise, increasing doctoral academic capacity, increasing scientific insight through seminars, and increasing ability in foreign languages.

Several points of human resource development planning, especially lecturers, are something that is likely to be achieved if the college is committed to implement it and makes the strategic plan as a guide in carrying out various activities to run the institution within the programmed 15 year period. The college actually has several plans related to

${ }^{24}$ Ibid., p. 21. 
the development of lecturer quality as contained in the strategic plan described in the previous section. Those are still in the form of planning, and the plans are also carried out at meetings. However, the researcher believes that the college has actually made other plans, because in the next section of the interview, it was stated that the lecturers were supported to increase their academic capacity through further studies. To increase the academic capacity of permanent lecturers who still in Masters Degrees through further studies, the funding is expected to be through the funding offered by the Ministry of Religion for the 5000 doctoral program, then funding for further studies from the other scholarship providers.

The program referred to the form of an educational improvement program for master lecturers, namely further studies at the doctoral level. This doctoral program is expected to be funded through scholarships offered by the Ministry of Religion, such as 5000 Doctorates program, scholarships offered by the ministry of finance, such as LPDP scholarships, study funding assistance from BAZIS, and so on. In addition, further study is also given the opportunity for lecturers who wish to undertake further studies at their own expense. In this regard, the college has various considerations and individual achievement targets. ${ }^{25}$

One of the plans that has been made by STAIN is to collaborate with various agencies, and ask for assistance from partners to provide further study funding assistance to their lecturers. This has been done to the BAZIS in Central Aceh Regency. In addition, the institution provides opportunities for those who have economic abilities to pay for their education personally. The efforts done by the college shows that they have a good plan related to the development of the quality of their human resources. The plan carried out by this institution proves their concern for the importance of increasing the capacity of lecturers; they are realized that in order to produce qualified alumni, they must have qualified resources, especially qualified lecturers.

From the analysis, it can be concluded that the State Islamic College has carried out various plans for the development of the quality of lecturers as outlined in its strategic plan and has also carried out planning and discussion at limited leadership meetings and leadership meetings with all lecturers at the beginning and at the end of the semester. The plan for developing the quality of lecturers covers of several important things, namely: 1) increasing the academic qualifications of lecturers with Masters degree to be Doctoral degree by utilizing scholarship funding provided by government and private scholarship providers. In this case, the institution provides motivation and permission for lecturers to take part in their further studies, and seeks to collaborate with various agencies to obtain scholarship assistance funds for lecturers; 2) involving lecturers in various training and other academic activities in increasing their professionalism; 3) organizing specific

${ }^{25}$ Ahmad Solihin, Quality Assurance of State Islamic College of Gajah Putih, interview in Takengon, August 16, 2019. 
training to improve the ability of lecturers in the field of research, and involving lecturers in research grants competitions and motivating them to publish their research results in accredited national journals or reputable international journals; and 4) making efforts to accelerate the improvement of lecturer's functional positions to be professors.

Each state Islamic high education has made plans for developing the quality of lecturers based on their conditions and abilities. The development plans are outlined in their strategic plan document. The beginning and the end of the year meetings become their opportunity of discussing plans outlined in the strategic plan, and at the same time accumulating various suggestions and inputs related to the plan concerned, and several things that had not been outlined in the strategic plan could appear at the meeting, and it will become even clearer in its implementation.

At the UIN level, the planning is known to be better than that of IAIN and STAIN. In its strategic plan, UIN makes plans with more confidence. There are many things they will do to increase the capacity of their lecturers. This is known because the ability of UIN in various aspects is better than that of IAIN and STAIN. The aspects of existing human resources and aspects of better budget availability are very decisive factors in making plans to develop the quality, because almost every program requires a large budget. Therefore, IAIN and STAIN are, of course, underneath. The availability of a smaller budget made it difficult for the two higher education to make completed plans.

Furthermore, it can be concluded that those higher education in Aceh have a fairly good plan regarding the development of the quality of its respective lecturers. The quality development plan is also discussed and followed up at several leadership meetings at the beginning and at the end of the academic year or semester. Broadly speaking, the development of the quality of lecturers is focused on several things, namely: 1) plans in terms of lecturer expertise by increasing the academic qualifications of lecturers by encouraging and giving permission for lecturers who still hold Masters degrees to take further studies at the doctoral level. Lecturers with Doctoral degrees are given opportunity to follow shortcourse program through various education funding programs both from within the country and abroad; 2) plan to increase the capacity and professionalism of lecturers as well as to accelerate the increase in functional positions to become professors by engaging them in various scientific meetings; 3 ) lecturer quality improvement plan through giving reward for lecturers who have successfully published their scientific papers in national or international journals; and 4) plans to facilitate lecturers in conducting research and community service.

\section{Conclusion}

Based on the results of the research and discussion above, it can be concluded that the plan to develop the quality of lecturers has been carried out properly in accordance with the capabilities and conditions of the State Islamic Religious College itself. Most of 
these development plans have been outlined in strategic plans and some of the others are made in important meetings. In its planning, there are important things to be considered, namely the state of human resources and existing facilities, and the availability of finance and financial resources at hand. Therefore, in planning various programs to support the need for quality development of the lecturers, UIN has a better self-confidence compared to IAIN and STAIN.

The plan for developing the quality of the lecturers above, in general, is in accordance with the provisions of the criteria for lecturers and the lecturer quality management stated in the previous section above, that the Islamic higher educations in Aceh have made a plan or program in realizing the achievement of qualified and professional lecturers. Planning made by those academic institutions in Aceh covers: 1) plans to turn lecturers into experts in their fields; 2) plans to develop lecturer expertise; and 3) plans to increase research and community service. These three institutions generally has the same commitment to make various good and sufficient plans for the development of the lecturer quality both in terms of capacity and professionalism, however there are two important aspects that determine policy makers in determining their plans. These aspects are 1) existing human resources and facilities, and 2) availability of funds and sources of funds owned by each institution.

Therefore, in order for the development of the quality of lecturers to be carried out properly at IAIN and STAIN, there must be other sources of funds that are lawful in addition to funding sources from the Government and students to support the program. Finally, the researchers acknowledges their shortcomings that it only carry out the planning stage, therefore it is hoped that other researchers will conduct research at the implementation and evaluation stages of the lecturer quality development.

\section{References}

Alzeaideen, Khaled. "The Effect of Tota Quality Management on University Performance in Jordan," in International Journal of Financial Research, Vol. 10, No. 6, 2019.

Anonym. Data EMIS PTKI-Dashboard Monitoring, in http://emisdep.kemenag.go.id/ ptkidashboard/ 23 September 2020.

Anonym. Rencana Strategis (Renstra) Institut Agama Islam Negeri Langsa Tahun 2015-2019.

Anonym. Rencana Strategis (Renstra) Sekolah Tinggi Agama Islam Negeri Gajah Putih, Takengon Tahun 2013-2029.

Anonym. Rencana Strategis (Renstra) Universitas Islam Negeri Ar Raniry Banda Aceh Tahun 2015-2019.

Anonym. Undang-Undang Republik Indonesia Nomor 14 tahun 2005 tentang Guru dan Dosen. 
Anonym. Undang-Undang Republik Indonesia Nomor 20 tahun 2003 tentang Sistem Pendidikan Nasional

Arwildayanto. Manajemen Sumber Daya Manusia Perguruan Tinggi: Pendekatan Budaya Kerja Dosen Profesional. Gorontalo: Ideas Publishing, 2012.

Asmawi, Muhammad Rosul. "Lecturer Quality Empowerment Strategy in Realizing National Education Objectives," in Perpektif: Jurnal Ilmu Administrasi, Vol. 1, No. 2, 2019.

Assan, Thomas Buabeng. "Perceptions of Lecturers on Quality Assurance in Higher Education Teaching and Learning Process," in International Journal of Educational Sciences, Vol. 7, 2014.

Bogdan, Robert C. and Kopp Sari Biklen. Qualitative Research forEducation: An Introduction to Theory and Methods. Boston London: Allyn and Bacon Inc, 1982.

Bungin, Burhan. Penelitian Kualitatif Komunikasi, Ekonomi, Kebijakan Publik, dan Ilmu Sosial. Second Edition. Jakarta: Kencana, 2011.

Castetter, William B. The Personnel Function in Educational Administration (3rd Edition). London: Collier Macmillan Publishers, 1981.

Cristianingsih, Endah. "Manajemen Mutu Perguruan Tinggi (Studi tentang Kepemimpinan Visioner dan Kinerja Dosen terhadap Mutu Perguruan Tinggi Swasta di Kota Bandung," in Manajerial, Vol. 9, No. 18, Januari 2011.

Dani, Awis Hamid, et al. "Manajemen Peningkatan Mutu Penelitian Dosen di Perguruan Tinggi Kesehatan Cirebon," in NER, Vol. 2, No. 3, 2019.

Fandy, Tjiptono and Anastasia Diana.Total Quality Management. Yogyakarta: Andi, 2009.

Gore, Jennifer, et al. "Effects of Professional Development on the Quality of Teaching: Results from a randomized controlled trial of quality teaching rounds," in Teaching and Teacher Education, Vol. 68, 2017.

Hadiantini, Ratih, et al. "Lecturer Performance Factors in Private Universities in Bandung City," in International Journal of Human Resource Studies, Vol. 7, No. 4, 2017.

Istan, Muhammad, et al. "The Effect of Academic Portal Use of Lecturer's Performance," in International Journal of Innovative Technology and Exploring Engineering (IJITEE), Vol. 9, Issue 3, 2020.

Kemal, Isthifa, et al. "Management of Lecturers Resource Development at Higher Education," in International Journal of Higher Education, Vol. 8, No. 5, 2019.

Knol MH, Dolan CV, Mellenbergh GJ, van der Maas HLJ. "Measuring the Quality of University Lectures: Development and Validation of the Instructional Skills Questionnaire (ISQ)," in PLOS ONE, Vol. 11, No. 2, 2016.

Kurniawan, Asep. "Hubungan Sertifikasi Dosen dan Gaya Kepemimpinan Rektor Dengan Produktivitas Kerja Dosen," in JIEM (Journal of Islamic Education Management, Vol. 4, No. 1, 2020.

Kusnan. "Kebijakan Peningkatan Mutu Dosen," in Jurnal Pendidikan Islam Iqra', Vol. 11, No. 2, 2017. 
Lisnasari, Srie Faizah. "The Quality Management of Higher Education on the Job Performance of Lecturers Basis," in Advances in Social Sciencies Research Journal, Vol. 5, No. 11, 2018.

Lucander, Henriette \& Cecilia Christersson. "Engagement for Quality Development in Higher Education: a Process for Quality Assurance of Assessment," in Quality in Higher Education, Vol. 26, No. 2, 2020.

Martin, Fuad dan Nurhattati. Manajemen Sarana dan Prasarana Pendidikan. Jakarta: RajaGrafindo Persada, 2016.

Mizaj. Quality Assurance of State Islamic University of Ar Raniry, interview di Banda Aceh, 2019.

Muhaimin. Wacana Pengembangan Pendidikan Islam. Surabaya: Pustaka Pelajar, 2003.

Muhtifah, Lailial, et al. "Jaminan dan Peningkatan Kualitas Dosen melalui Program Doktor pada PTKIN di Indonesia," in ALFIKR: Jurnal Pendidikan Islam, Vol. 4, No. 2, 2018.

Muslim, Bukhori. Quality Assurance of State Islamic University of Ar Raniry, interview in Banda Aceh, 2019.

Nur, Hasan. Konvensi Nasional Pendidikan Indonesia, Kurikulum untuk Abad 21: Indikator Cara Pengukuran dan Faktor-faktor yang Mempengaruhi Mutu Pendidikan. Jakarta: IRCiSoD, 2011.

Ramdhan, Dadan F. and Hariman Surya Siregar. "Manajemen Mutu Perguruan Tinggi Keagamaan Islam Swasta (PTKIS)," in Jurnal Perspektif, Vol. 3, No. 1, 2019.

Razak, Yusran, et al. "Kepemimpinan, Kinerja Dosen dalam Peningkatan Mutu Pendidikan Perguruan Tinggi," in TANZIM: Jurnal Penelitian Manajemen Pendidikan, Vol. 1, No. 2 , 2016.

Sallis, M. Edward.Total Quality Management in Education,tr. Ahmad Ali Riyadi and Fahrurrozi. Jogjakarta: Ircisod, 2010.

Siagian, Sondang P. Manajemen Sumber Daya Manusia. Jakarta: Bumi Aksara, 2008.

Simangunsong, Eliot. "Factor determining the Quality Management of Higher Education: A Case Study at a Business School in Indonesia," in Cakrawala Pendidikan, Vol. 38, No. 2, 2019.

Sitorus, Masganti. Metodologi Penelitian Pendidikan Islam. Medan: IAIN Press, 2011.

Solihin, Ahmad. Quality Assurance of State Islamic College of Gajah Putih, interview in Takengon, 2019.

Sopiah and Etta Mamang Sangadji. "The Effect of Lecturer Commitment on Student Academic Achievement toward Student Satisfaction through Perceived Teaching Quality," in Jurnal Ilmu Pendidikan, Vol. 25, No. 2, 2019.

Suarman. "Teaching Quality and Students Satisfaction: The Intermediatory Role of Relationship between Lecturers and Students of the Higher Learning Institutes," in Mediterranean Journal of Social Sciences, Vol. 6, No. 2, 2015. 
Suib, Masluyah. "Kebijakan dan Pengembangan Mutu Dosen," in Cakrawala Kependidikan, Vol. 9, No. 2, 2011.

Sulistianingsih, Endang, et al. "The Effect of Lecturer's Competence and Learning Process Quality on Student's Satisfaction," in International Journal of Engineering \& Technology, Vol. 7, No. 3.21, 2018.

Suryaman. "Indonesian Private University Lecturer Performance Improvement Model to Improve a Sustainable Organization Performance," in International Journal of Higher Education, Vol. 7, No. 1, 2018.

Syaodih, Nana Sukmadinata. Pengendalian Mutu Pendidikan Sekolah Menengah, Konsep, Prinsip, dan Instrumen. Bandung: Refika Aditama, 2006.

Warits, Abdul. Strategi Pengembangan Mutu Perguruan Tinggi Keagamaan Islam Berbasis Pesantren: Studi Multi kasus pada Institut Ilmu Keislaman Annuqayah dan Institut Dirosat Islamiyah Al-Amien Kabupaten Sumenep Madura. Malang: UIN Malang, 2015.

Yusaini. Quality Assurance, State Islamic Institute of Langsa, interview di Langsa, 2019.

Zulfahmi, Sarwo, et al. "An Analysis of Lecturer Perception on the Use of E-Learning for English Instruction in IAIN Kendari," in JLEET: Journal of Language Education and Educational Technology, Vol. 3, No. 2, 2018. 